\title{
Pengaruh pemberian ekstrak kedelai hitam (Glycine soja.) berbagai dosis terhadap kadar glukosa darah, kadar insulin, dan HOMA-IR
}

\author{
Dewi M Kurniawati ${ }^{1 *}$, Edi Dharmana ${ }^{2}$, Banundari Rachmawati ${ }^{3}$, Tjokorda Gde Dalem Pemayun $^{4}$
}

\begin{abstract}
Background: Obese is risk factor for abnormal glucose homeostasis and causes oxidative stress that can decrease insulin sensitivity resulting in hyperglycemia and hyperinsulinemia. Black soy bean contains anthocyanins and isoflavones, it is expected to reduce oxidative stress.

Objective: Determine the effect of various dosage of black soybean extract (Glycine soja.) on blood glucose, insulin levels, and HOMA - IR in obese Sprague Dawley (SD) rats.

Methods: True experimental study with randomized controlled pre test-post test design in male SD rats. Twenty four samples divided into 4 groups: control (K), 500 (P1), 750 (P2), and $1000 \mathrm{mg} / \mathrm{kgBW}(P 3)$. Rats were induced to become obese with High Fat Sucrose Diet (HFSD) for 4 weeks then black soybean extracts were given for 2 weeks..

Results: There was no difference in blood glucose before and after treatment ( $p>0.05)$. There were differences on insulin levels in $500(p=0.012)$ and $750 \mathrm{mg} / \mathrm{kgBW}(p=0.020)$ doseges. There were differences on HOMA-IR in $500(p=0.043)$ and $750 \mathrm{mg} / \mathrm{kgBW}(p=0.028)$ dosages. There was difference in insulin levels's difference $(p=0.009)$ between groups.

Conclusion: There are differences on insulin levels and HOMA - IR in 500 and $750 \mathrm{mg} / \mathrm{kgBW}$ dosages groups. However, there is no difference on blood glucose before and after black soybean extract treatment. The most decreased levels of blood glucose, insulin and HOMA- IR were in $750 \mathrm{mg} / \mathrm{kgBW}$ dosage.
\end{abstract}

Keyword: Obese; hyperglycemia; insulin; black soybean extract

\begin{abstract}
ABSTRAK
Latar belakang: Obesitas merupakan faktor resiko homeostasis glukosa yang tidak normal dan memicu stres oksidatif sehingga dapat menurunkan sensitivitas insulin yang menyebabkan hiperglikemia dan hiperinsulinemia. Kedelai hitam mengandung antioksidan antosianin dan isoflavon yang diharapkan dapat mengurangi stres oksidatif.

Tujuan: Mengetahui pengaruh ekstrak kedelai hitam (Glycine soja.) berbagai dosis terhadap kadar glukosa darah, kadar insulin, dan HOMA-IR pada tikus Sprague Dawley (SD) obesitas.

Metode: True eksperimental dengan rancangan randomized controlled pre test-post test design pada tikus SD jantan. Dua puluh empat sampel dibagi 4 kelompok: kontrol (K), dosis 500 (P1), 750 (P2), dan $1000 \mathrm{mg} / \mathrm{kgBB}$ (P3). Tikus dibuat obesitas dengan high fat sucrose diet (HFSD) selama 4 minggu kemudian diberi ekstrak kedelai hitam selama 2 minggu.

Hasil: Tidak ada perbedaan kadar glukosa darah sebelum dan setelah perlakuan $(p>0,05)$. Ada perbedaan kadar insulin dosis $500(p=0,012)$ dan $750 \mathrm{mg} / \mathrm{kgBB}(p=0,020)$ serta ada perbedaan HOMA-IR dosis $500(p=0,043)$ dan $750 \mathrm{mg} / \mathrm{kgBB}(p$ $=0,028)$. Terdapat perbedaan selisih kadar insulin $(p=0,009)$ antar kelompok.

Simpulan: Ada perbedaan kadar insulin dan HOMA-IR pada dosis 500 dan $750 \mathrm{mg} / \mathrm{kgBB}$, namun kadar glukosa darah sebelum dan setelah pemberian ekstrak kedelai hitam tidak berbeda. Penurunan kadar glukosa darah, kadar insulin, dan HOMA-IR terbesar terdapat pada dosis $750 \mathrm{mg} / \mathrm{kgBB}$.
\end{abstract}

Kata kunci: obesitas; hiperglikemia; insulin; ekstrak kedelai hitam

\section{PENDAHULUAN}

Obesitas adalah terjadinya penumpukan lemak yang berlebihan dalam tubuh yang dapat

\footnotetext{
1. Program Studi Ilmu Gizi, Departemen Ilmu Gizi, Fakultas Kedokteran, Universitas Diponegoro. Jl. Prof. Soedarto SH Tembalang, Semarang 50275

2. Bagian Parasitologi Fakultas Kedokteran, Universitas Diponegoro. Kompleks RSUP Dr. Kariadi, Jln. Dr. Sutomo No.16, Randusari, Semarang 50244

${ }^{3 .}$ Bagian Patologi Klinik Fakultas Kedokteran, Universitas Diponegoro. Kompleks RSUP Dr. Kariadi, Jln. Dr. Sutomo No.16, Randusari, Semarang 50244

4. Bagian Penyakit Dalam Fakultas Kedokteran, Universitas Diponegoro. Kompleks RSUP Dr. Kariadi, Jln. Dr. Sutomo No.16, Randusari, Semarang 50244

"Korespondensi: Email: dewimkurniawati@fk.undip.ac.id
}

menyebabkan gangguan metabolik diataranya Diabetes Melitus (DM), penyakit kardiovaskuler, Non-Alcoholic Fatty Liver Disease (NAFLD), dislipidemia, dan gangguan metabolisme lain., ${ }^{1,2}$ Homeostasis glukosa merupakan proses untuk mempertahankan kadar glukosa yang stabil dalam darah. ${ }^{3}$ Namun, pada kondisi obesitas, homeostasis glukosa akan terganggu. ${ }^{4}$ Resiko Diabetes Melitus Tipe 2 (DM Tipe 2) meningkat pada kondisi obesitas. Menurut World Health Organization (WHO), pada tahun 2008 sebanyak 10\% laki-laki dan 14\% perempuan dewasa di dunia mengalami obesitas. ${ }^{5}$ Selain itu, WHO juga memprediksi peningkatan pasien DM di Indonesia dari 8,4 juta pada tahun 2000 menjadi sekitar 21,3 juta pada tahun $2030 .^{6}$ 
Hubungan antara obesitas dan DM Tipe 2 dapat dijelaskan melalui 2 mekanisme yaitu resistensi insulin terkait obesitas dan kegagalan fungsi sel beta pankreas. Obesitas dan gangguan metabolisme dapat menyebabkan dekompensasi sel beta, jika hal tersebut berlangsung dalam jangka waktu yang lama, maka akan menyebabkan hiperglikemia dan hiperinsulinemia. ${ }^{7}$ Kelainan metabolisme tubuh di mana terjadi penurunan respon atau sensitivitas aksi insulin disebut resistensi insulin. ${ }^{8}$ Resistensi insulin terkait obesitas yang diketahui lebih awal, diharapkan dapat mencegah risiko DM Tipe 2 atau memperlambat tingkat keparahannya. Homeostasis Model Asessment of Insulin Resistance (HOMA-IR) merupakan salah satu indeks pemeriksaan resistensi insulin. Nilai HOMA-IR dapat diukur dari kadar insulin puasa (mIU/l) dan glukosa puasa $(\mathrm{mmol} / \mathrm{l}) .{ }^{9}$

Obesitas selain menyebabkan resistensi insulin juga dapat menyebabkan stres oksidatif. ${ }^{4}$ Stres oksidatif adalah ketidakseimbangan antara reactive oxygen species (ROS) dengan pertahanan antioksidan dalam tubuh. ${ }^{10}$ Aktivasi Protein kinase $C-\theta$ (PKC- $\left.\theta\right)$ dan Protein kinase $C-\varepsilon$ (PKC- $\varepsilon$ ) pada otot skeletal dan hati salah satunya dipicu oleh peningkatan asam lemak bebas dan ROS. Aksi insulin akan terganggu oleh kinase tersebut melalui mekanisme penghambatan fosforilasi protein IRS pada jalur PI-3kinase. ${ }^{11}$ Di otot, mekanisme tersebut akan menurunkan sintesis glikogen otot dan menurunkan translokasi GLUT-4 di membran plasma, sedangkan di hati, mekanisme tersebut akan menurunkan sintesis glikogen hati, meningkatkan glukoneogenesis hati serta menurunkan aktivasi glikogen sintase. ${ }^{12}$

Terdapat beberapa zat antioksidan yang berperan dalam memperbaiki gangguan metabolisme glukosa, mencegah resistensi insulin, mengatasi inflamasi intraseluler dan menurunkan terjadinya stress oksidatif. Salah satu bahan pangan yang memiliki kandungan antioksidan tinggi adalah kedelai hitam. Kedelai hitam (Glycine soja.) memiliki kandungan antioksidan yang lebih tinggi dibandingkan dengan kedelai kuning dan hijau. ${ }^{13}$ Kandungan antioksidan dalam 100 gram kedelai hitam terdiri dari 222,49 $\mathrm{mg}$ antosianin dan $367,00 \mathrm{mg}$ isoflavon. ${ }^{14}$

Penelitian yang menunjukkan efektivitas antosianin atau isoflavon dalam memperbaiki aksi insulin telah dilakukan sebelumnya. Pemberian jagung ungu dan ekstrak bilberry yang mengandung antosianin diketahui dapat meningkatkan sensitivitas insulin. ${ }^{15,16}$ Penelitan lain menunjukkan bahwa ekstrak kedelai hitam dapat menurunkan kadar glukosa darah dan superoksida dismutase (SOD). ${ }^{17}$ Namun, penelitian mengenai kedelai hitam yang berperan dalam memperbaiki gangguan metabolisme glukosa, menurunkan kadar glukosa darah dan meningkatkan sensitivitas insulin beum pernah dilakukan. Penelitian ini bertujuan untuk mengetahui pengaruh pemberian ekstrak kedelai hitam (Glycine soja.) berbagai dosis terhadap kadar glukosa darah, kadar insulin, dan HOMA-IR pada tikus Sprague Dawley obesitas yang diberi high fat sucrose diet (HFSD).

\section{BAHAN DAN METODE}

Jenis penelitian eksperimental dengan rancangan randomized controlled pre test-post test design. Pemeliharaan hewan coba dilakukan selama 7 minggu di Laboratorium Penelitian dan Pengujian Terpadu - Layanan Penelitian Pra Klinik Pengembangan Hewan Percobaan (LPPT-LP3HP) Universitas Gadjah Mada Yogyakarta (UGM).

Subjek penelitian adalah tikus Sprague Dawley jantan dengan umur 6 minggu dan berat badan antara 120 - 180 gram. Besar sampel dihitung mengacu pada standar WHO, yaitu 5 ekor tiap perlakuan. Namun, untuk mengatasi dropout peneliti menggunakan 6 ekor. Penelitian ini terdiri dari 1 kelompok kontrol dan 3 kelompok perlakuan, sehingga total sampel adalah 24 ekor.

Fase adaptasi dilakukan selama 7 hari, kemudian semua kelompok diberi diet High Fat Sucrose Diet (HFSD) secara oral selama 4 minggu. Diet tinggi lemak diberikan sebanyak $21 \%$ dari total asupan makan dibuat dari minyak babi sebesar $15 \%$ dan kuning telur sebesar $6 \%$ yang dicampur hingga homogen. Diet tinggi sukrosa sebesar 34\% dari total asupan makan dibuat dari sukrosa murni dan aquadest dengan konsentrasi $100 \% .{ }^{18}$ Pemeriksaan berat badan dan panjang badan dilakukan setelah pemberian HFSD selama 4 minggu untuk menentukan tikus yang masuk dalam kriteria obesitas menurut indeks Lee. Tikus dinyatakan obesitas jika nilai indeks obesitas Lee >0,300. ${ }^{19}$ Tikus yang memenuhi kriteria dibagi menjadi 4 kelompok secara acak.Kelompok kontrol (K) yang diberi HFSD, kelompok perlakuan 1 (P1) diberi HFSD dan ekstrak kedelai hitam $500 \mathrm{mg} / \mathrm{kgBB}$, kelompok perlakuan 2 (P2) diberi HFSD dan ekstrak kedelai hitam 750 mg dan kelompok perlakuan 3 (P3) diberi HFSD dan ekstrak kedelai hitam 1000 $\mathrm{mg} / \mathrm{kgBB}$. Pemberian ektrak kedelai hitam dilakukan selama 2 minggu sesuai dengan dosis masing-masing kelompok. ${ }^{17}$

Pengukuran kadar glukosa darah dan insulin dilakukan sebelum dan setelah pemberian ekstrak kedelai hitam. Pemeriksaan kadar glukosa darah diukur dengan metode GOD-PAP dan tikus sebelumnya dipuasakan selama 12 jam. Kadar insulin diperiksa menggunakan metode ELISA dengan gelombang pembacaan $450 \mathrm{~nm}$ yang diukur setelah tikus dipuasakan 12 jam. Nilai HOMA-IR merupakan gambaran kemampuan aksi metabolik insulin yang 
dapat dilihat dari dari konsentrasi insulin puasa (mIU/l) dan glukosa puasa (mmol/l).

Pembuatan ekstrak kedelai hitam dilakukan di Laboratorium Teknologi Pangan UNIKA Soegijapranata. Kedelai hitam varietas Mallika dibersihkan dan dicuci terlebih dahulu, kemudian dikeringkan menggunakan oven pada suhu $40^{\circ} \mathrm{C}$. Kedelai hitam yang telah dikeringkan kemudian dihaluskan hingga menjadi serbuk simplisia. Simplisia kemudian ditempatkan pada wadah kaca dan dicampur dengan ethanol $70 \%$. Larutan tersebut kemudian diaduk, ditutup rapat, dan direndam selama 5 hari pada suhu ruang. Setelah 5 hari, rendaman disaring menggunakan kertas saring untuk memperoleh filtratnya. Filtrat yang diperoleh kemudian dipekatkan dengan menggunakan rotary evaporator pada suhu $50^{\circ} \mathrm{C}$.

Ekstrak kedelai hitam selanjutnya diperiksa aktivitas antioksidan dan total flavonoidnya. Pemeriksaan aktivitas antioksidan menggunakan metode DPPH (1,1-difenil-2-pikrilhidrazil), sedangkan pemeriksaan total flavonoid menggunakan metode spektrofotometri visibel.

Data yang diperoleh diolah dengan program komputer. Normalitas data diuji menggunakan Saphiro-Wilk dilanjutkan uji t dan Wilcoxon untuk mengetahui perbedaan kadar glukosa darah, kadar insulin, dan nilai HOMA-IR sebelum dan sesudah pemberian ekstrak kedelai hitam. Uji One-way Anova dan Kruskal Wallis digunakan untuk mengetahui perbedaan selisih kadar glukosa darah, kadar insulin, dan HOMA-IR sebelum dan setelah pemberian ekstrak kedelai hitam (Glycine soja.) antar kelompok dosis. ${ }^{20}$

\section{HASIL}

\section{Karakteristik Hewan Coba}

Sampel hewan coba yang digunakan dalam penelitian ini adalah sebanyak 24 ekor. Terdapat satu hewan coba yang mati yang berasal dari kelompok kontrol selama penelitian ini berlangsung. Selain itu, terdapat satu data kadar insulin pada kelompok dosis $500 \mathrm{mg} / \mathrm{kgBB}$ (P1) yang nilainya terlalu tinggi dan menjadi outlier. Data tersebut tidak digunakan agar tidak mengganggu hasil penelitian.

Rerata berat badan hewan coba pada semua kelompok mengalami peningkatan setelah pemberian ekstrak kedelai hitam. Hasil analisis Tabel 1 menunjukkan tidak terdapat perbedaan bermakna pada rerata berat badan antara kelompok sebelum dan setelah perlakuan yang di tunjukan dengan nilai $\mathrm{p}$ yaitu 0,168 dan 0,239 (p>0.05). Hal ini menunjukkan bahwa variasi atau karakteristik antara kelompok perlakuan tidak berbeda bermakna. Rerata berat badan indeks obesitas disajikan pada Tabel 1.

Tabel 1. Berat Badan Hewan Coba

\begin{tabular}{|c|c|c|c|c|c|}
\hline \multirow[b]{2}{*}{ Kelompok } & \multicolumn{4}{|c|}{ Rerata Berat Badan (gram) } & \multirow[b]{2}{*}{$p$ antar kelompok } \\
\hline & $\begin{array}{c}\mathbf{K} \\
(\mathbf{x} \pm \mathrm{SD})\end{array}$ & $\begin{array}{c}\text { P1 } \\
(\mathrm{x} \pm \mathrm{SD})\end{array}$ & $\begin{array}{c}\text { P2 } \\
(x \pm S D)\end{array}$ & $\begin{array}{c}\text { P3 } \\
(\mathrm{x} \pm \mathrm{SD}) \\
\end{array}$ & \\
\hline Sebelum perlakuan & $233,12 \pm 19,75$ & $212,16 \pm 11,64$ & $206,22 \pm 26,15$ & $209,85 \pm 20,53$ & 0,195 \\
\hline Setelah perlakuan & $246,62 \pm 19,33$ & $228,22 \pm 12,28$ & $222,90 \pm 25,12$ & $227,93 \pm 20,55$ & 0,278 \\
\hline$\Delta \mathrm{BB}$ & $13,50 \pm 27,90$ & $16,06 \pm 3,77$ & $16,68 \pm 4,11$ & $18,08 \pm 2,45$ & \\
\hline
\end{tabular}

Keterangan: $\mathrm{K}=$ Kelompok kontrol; P1 = Kelompok perlakuan ekstrak kedelai hitam $500 \mathrm{mg} / \mathrm{kgBB}$; P2 = Kelompok perlakuan ekstrak kedelai hitam $750 \mathrm{mg} / \mathrm{kgBB} ; \mathrm{P} 3=$ Kelompok perlakuan ekstrak kedelai hitam $1000 \mathrm{mg} / \mathrm{kgBB} ; p=\mathrm{Nilai}$ signifikansi uji One Way Anova antar kelompok

Salah satu kriteria inklusi dalam penelitian ini adalah memenuhi indeks obesitas hewan coba menurut indeks obesitas Lee. ${ }^{68}$ Hewan coba dinyatakan obesitas jika indeks obesitas >0,300. Berdasarkan Tabel 2, terdapat perbedaan pada rerata berat badan antara kelompok sebelum dan setelah perlakuan yang di tunjukan dengan nilai $p$ yaitu 0,011 dan $0,016(\mathrm{p}<0,05)$. Hal ini dapat menunjukkan bahwa diantara kelompok penelitian memiliki indeks obesitas yang bervariasi. Rerata indeks obesitas tikus sebelum dan setelah pemberian ekstrak kedelai hitam disajikan pada Tabel 2.

\section{Kadar Glukosa Darah}

Berdasarkan tabel 3, rerata kadar glukosa darah sebelum dan setelah perlakuan mengalami penurunan pada semua kelompok. Kelompok yang mengalami penurunan glukosa darah terbesar terlihat pada kelompok P2 atau dosis $750 \mathrm{mg} / \mathrm{kgBB}$. Hasil analisis statistik menggunakan uji dependent t-test menunjukkan bahwa tidak terdapat perbedaan kadar glukosa darah sebelum dan setelah perlakuan yang ditunjukkan dengan nilai $\mathrm{p}>0,05$. 
Tabel 2. Indeks Obesitas Hewan Coba

\begin{tabular}{|c|c|c|c|c|c|}
\hline \multirow[b]{2}{*}{ Kelompok } & \multicolumn{4}{|c|}{ Nilai Tengah Indeks Obesitas } & \multirow[b]{2}{*}{$\begin{array}{c}p \text { antar } \\
\text { kelompok }\end{array}$} \\
\hline & $\begin{array}{c}\text { K } \\
\text { Median } \pm \\
(\text { Min-Maks })\end{array}$ & $\begin{array}{c}\text { P1 } \\
\text { Median } \pm \\
(\text { Min-Maks) } \\
\end{array}$ & $\begin{array}{c}\text { P2 } \\
\text { Median } \pm \\
(\text { Min-Maks })\end{array}$ & $\begin{array}{c}\text { P3 } \\
\text { Median } \pm \\
(\text { Min-Maks }) \\
\end{array}$ & \\
\hline Sebelum perlakuan & $\begin{array}{l}0,303 \pm \\
(0,303-0,312)\end{array}$ & $\begin{array}{l}0,309 \pm \\
(0,306-0,311)\end{array}$ & $\begin{array}{l}0,310 \pm \\
(0,307-0,311)\end{array}$ & $\begin{array}{l}0,313 \pm \\
(0,311-0,314)\end{array}$ & 0,012 \\
\hline Setelah perlakuan & $\begin{array}{l}0,302+ \\
(0,297-0,308)\end{array}$ & $\begin{array}{l}0,305 \pm \\
(0,303-0,308)\end{array}$ & $\begin{array}{l}0,306 \pm \\
(0,304-0,308)\end{array}$ & $\begin{array}{l}0,309 \pm \\
(0,306-0,313)\end{array}$ & 0,037 \\
\hline$\Delta$ Indeks Obesitas & $\begin{array}{l}0,001 \pm \\
(0,006-0,004)\end{array}$ & $\begin{array}{l}0,004 \pm \\
(0,003-0,003)\end{array}$ & $\begin{array}{l}0,004+ \\
(0,003-0,003)\end{array}$ & $\begin{array}{l}0,004 \pm \\
(0,005-0,001)\end{array}$ & \\
\hline
\end{tabular}

Keterangan: $\mathrm{K}=$ Kelompok kontrol; $\mathrm{P} 1=$ Kelompok perlakuan ekstrak kedelai hitam $500 \mathrm{mg} / \mathrm{kgBB} ; \mathrm{P} 2=\mathrm{Kelompok}$ perlakuan ekstrak kedelai hitam $750 \mathrm{mg} / \mathrm{kgBB} ; \mathrm{P} 3=$ Kelompok perlakuan ekstrak kedelai hitam $1000 \mathrm{mg} / \mathrm{kgBB} ; p=\mathrm{Nilai}$ signifikansi uji One Way Anova antar kelompok

Tabel 3. Kadar Glukosa Darah Hewan Coba

\begin{tabular}{|c|c|c|c|c|}
\hline \multirow[b]{2}{*}{ Kelompok } & \multicolumn{2}{|c|}{ Rerata Kadar Glukosa Darah (mg/dl) } & \multirow[b]{2}{*}{$\Delta$} & \multirow[b]{2}{*}{$\mathbf{p}$} \\
\hline & $\begin{array}{l}\text { Sebelum perlakuan } \\
\qquad(x \pm S D)\end{array}$ & $\begin{array}{l}\text { Setelah perlakuan } \\
\qquad(x \pm \text { SD })\end{array}$ & & \\
\hline $\mathrm{K}$ & $105,24 \pm 7,77$ & $94,82 \pm 5,66$ & $-10,42 \pm 6,09$ & 0,408 \\
\hline $\mathrm{P} 1$ & $108,66 \pm 15,89$ & $94,98 \pm 12,58$ & $-13,68 \pm 18,57$ & 0,435 \\
\hline $\mathrm{P} 2$ & $118,07 \pm 19,77$ & $95,83 \pm 12,91$ & $-22,23 \pm 19,40$ & 0,503 \\
\hline P3 & $122,70 \pm 11,24$ & $101,45 \pm 12,45$ & $-21,25 \pm 10,98$ & 0,778 \\
\hline
\end{tabular}

Keterangan: $\mathrm{K}=$ Kelompok kontrol; P1 = Kelompok perlakuan ekstrak kedelai hitam $500 \mathrm{mg} / \mathrm{kgBB}$; P2 = Kelompok perlakuan ekstrak kedelai hitam $750 \mathrm{mg} / \mathrm{kgBB}$; P3 = Kelompok perlakuan ekstrak kedelai hitam $1000 \mathrm{mg} / \mathrm{kgBB} ; \Delta=\mathrm{Selisih}$ rerata kadar glukosa sebelum dan setelah perlakuan; $\mathrm{p}=$ Nilai signifikansi uji dependent t-test dalam kelompok

\section{Kadar Insulin}

Tabel 4 menunjukkan rerata kadar insulin sebelum dan setelah perlakuan mengalami penurunan pada kelompok P1 dan P2. Kelompok yang mengalami penurunan kadar insulin paling tinggi terlihat pada kelompok P2, sedangkan kelompok P3 atau dosis $1000 \mathrm{mg} / \mathrm{kgBB}$ justru mengalami peningkatan. Hasil uji dependent t-test menunjukkan adanya penurunan kadar insulin pada kelompok dosis $500 \mathrm{mg} / \mathrm{kg}(\mathrm{p}=0,012)$ dan dosis $750 \mathrm{mg} / \mathrm{kgBB}(\mathrm{p}=$ 0,020 ).

Tabel 4. Kadar Insulin Hewan Coba

\begin{tabular}{ccccc}
\hline \multirow{2}{*}{ Kelompok } & \multicolumn{2}{c}{ Rearata Kadar Insulin $(\mu \mathbf{\mu} / \mathbf{m l})$} & & \\
\cline { 2 - 5 } & \multicolumn{1}{c}{$\begin{array}{c}\text { Sebelum perlakuan } \\
(\mathbf{x} \pm \mathbf{S D})\end{array}$} & $\begin{array}{c}\text { Setelah perlakuan } \\
(\mathbf{x} \pm \mathbf{S D})\end{array}$ & $\mathbf{\Delta}$ & \\
\hline K & $9,38 \pm 1,53$ & $7,38 \pm 0,59$ & $-2,00 \pm 2,12$ & 0,103 \\
P1 & $11,36 \pm 2,64$ & $7,59 \pm 1,11$ & $-3,57 \pm 1,91$ & 0,012 \\
P2 & $11,84 \pm 3,28$ & $8,23 \pm 1,42$ & $-3,61 \pm 2,64$ & 0,020 \\
P3 & $8,91 \pm 0,67$ & $10,54 \pm 3,97$ & $1,63 \pm 3,57$ & 0,315 \\
\hline
\end{tabular}

Keterangan: $\mathrm{K}=$ Kelompok kontrol, $\mathrm{P} 1=$ Kelompok perlakuan ekstrak kedelai hitam $500 \mathrm{mg} / \mathrm{kgBB}, \mathrm{P} 2=\mathrm{Kelompok}$ perlakuan ekstrak kedelai hitam $750 \mathrm{mg} / \mathrm{kgBB}, \mathrm{P} 3=$ Kelompok perlakuan ekstrak kedelai hitam $1000 \mathrm{mg} / \mathrm{kgBB}, \Delta=\mathrm{Selisih}$ rerata kadar glukosa sebelum dan setelah perlakuan, $\mathrm{p}=$ Nilai signifikansi uji dependent $t$-test dalam kelompok

\section{HOMA-IR}

Berdasarkan tabel 5, HOMA-IR sebelum dan setelah penelitian mengalami penurunan pada semua kelompok. Kelompok yang mengalami penurunan glukosa darah terbesar terlihat pada kelompok P2 atau dosis $750 \mathrm{mg} / \mathrm{kgBB}$. Hasil analisis statistik menggunakan uji Wilcoxon menunjukkan adanya perbedaan nilai HOMA-IR sebelum dan setelah perlakuan pada kelompok dosis $500 \mathrm{mg} / \mathrm{kg}(\mathrm{p}=0,043)$ dan dosis $750 \mathrm{mg} / \mathrm{kgBB}(\mathrm{p}=0,028)$.
Selisih kadar glukosa darah, kadar insulin, dan HOMA-IR

Selisih kadar glukosa darah, kadar insulin, dan HOMA-IR diperoleh dari rerata sebelum perlakuan dikurangi rerata setelah perlakuan. Kelompok P1 memiliki selisih yang lebih besar jika dibandingkan dengan kelompok kontrol. Selisih atau penurunan rerata kadar glukosa, kadar insulin dan HOMA-IR terlihat semakin besar pada kelompok P2. Namun pada kelompok P3, selisih yang terjadi justru lebih kecil jika dibandingkan dengan kelompok P2. Tabel 6 
menunjukkan bahwa rerata penurunan kadar glukosa darah, kadar insulin, dan nilai HOMA-IR penurunan terbesar terdapat pada kelompok dosis $750 \mathrm{mg} / \mathrm{kgBB}$. Berdasarkan hasil analisis, terdapat perbedaan ekstrak kedelai hitam terhadap selisih kadar insulin antar kelompok dosis, hal tersebut dapat dilihat dari nilai $\mathrm{p}$ sebesar 0,009 $(\mathrm{p}<0,05)$.

Tabel 5. HOMA-IR Hewan Coba

\begin{tabular}{ccccc}
\hline \multirow{2}{*}{ Kelompok } & \multicolumn{2}{c}{ Nilai Tengah HOMA-IR } & \multicolumn{1}{c}{ p } \\
\cline { 2 - 5 } & $\begin{array}{c}\text { Sebelum perlakuan } \\
\text { Median } \pm \text { (Min-Maks) }\end{array}$ & $\begin{array}{c}\text { Setelah perlakuan } \\
\text { Median } \pm \text { (Min-Maks) }\end{array}$ & $-0,88 \pm 0,49$ \\
K & $2,56 \pm(1,976-4,963)$ & $1,68 \pm(1,396-2,123)$ & 0,800 \\
P1 & $2,96 \pm(1,974-4,963)$ & $1,84 \pm(1,396-2,123)$ & $-1,12 \pm 0,97$ & 0,043 \\
P2 & $3,09 \pm(1,992-5,521)$ & $1,80 \pm(1,459-2,739)$ & $-1,29 \pm 1,01$ & 0,028 \\
P3 & $2,69 \pm(2,436-2,951)$ & $2,38 \pm(1,938-4,276)$ & $-0,31 \pm 0,82$ & 0,463 \\
\hline
\end{tabular}

Keterangan: $\mathrm{K}=$ Kelompok kontrol; $\mathrm{P} 1=$ Kelompok perlakuan ekstrak kedelai hitam $500 \mathrm{mg} / \mathrm{kgBB} ; \mathrm{P} 2=\mathrm{Kelompok}$ perlakuan ekstrak kedelai hitam $750 \mathrm{mg} / \mathrm{kgBB} ; \mathrm{P} 3=$ Kelompok perlakuan ekstrak kedelai hitam $1000 \mathrm{mg} / \mathrm{kgBB} ; \Delta=\mathrm{Selisih}$ rerata HOMA-IR sebelum dan setelah perlakuan; $\mathrm{p}=$ Nilai signifikansi uji Wilcoxon dalam kelompok

Tabel 6. Selisih Kadar Glukosa Darah dan Kadar Insulin, dan HOMA-IR

\begin{tabular}{lccccc}
\hline \multirow{1}{*}{ Kelompok } & \multicolumn{4}{c}{$\Delta$ Sebelum Dan Setelah Permberian Ekstrak Kedelai Hitam } \\
\cline { 2 - 5 } & $\mathbf{K}$ & $\mathbf{P 1}$ & $\mathbf{P 2}$ & $\mathbf{P 3}$ & $\mathbf{P}$ \\
\hline Kadar Glukosa Darah & $-10,42 \pm 6,09$ & $-13,68 \pm 18,57$ & $-22,23 \pm 19,40$ & $-21,25 \pm 10,98$ & $0,572^{\mathrm{a}}$ \\
Kadar Insulin & $-2,00 \pm 2,12$ & $-3,57 \pm 1,91$ & $-3,61 \pm 2,64$ & $1,63 \pm 3,57$ & $0,009^{\mathrm{b}}$ \\
Nilai HOMA-IR & $-0,71 \pm 0,49$ & $-1,34 \pm 0,97$ & $-1,58 \pm 1,01$ & $-0,10 \pm 0,82$ & $0,058^{\mathrm{b}}$ \\
\hline
\end{tabular}

Keterangan: $\mathrm{K}=$ Kelompok kontrol; P1 = Kelompok perlakuan ekstrak kedelai hitam 500 mg/kgBB; P2 = Kelompok perlakuan ekstrak kedelai hitam $750 \mathrm{mg} / \mathrm{kgBB}$; P3 = Kelompok perlakuan ekstrak kedelai hitam $1000 \mathrm{mg} / \mathrm{kgBB}$; a = Nilai signifikansi uji One way Anova antar kelompok; b = Nilai signifikansi uji Kruskal Wallis antar kelompok

\section{PEMBAHASAN}

\section{Kadar Glukosa Darah}

Penelitian ini menunjukkan bahwa kadar glukosa darah pada semua kelompok perlakuan mengalami penurunan, walaupun secara statistik tidak terdapat perbedaan kadar glukosa darah sebelum dan setelah pemberian ekstrak kedelai hitam berbagai dosis. Hasil penelitian ini berbeda dengan penelitian Takikawa, penelitian tersebut menunjukkan bahwa pemberian jus anggur-bilberry dapat menurunkan kadar glukosa darah. ${ }^{16}$

Ekstrak kedelai hitam memiliki kandungan isoflavon yang bermanfaat untuk mencegah peroksidasi lipid yang diinduksi glukosa. ${ }^{21}$ Selain itu genistein bermanfaat dalam menghambat $\alpha$ glukosidase yang berperan pada beberapa kelainan metabolik. ${ }^{22}$ Oleh sebab itu, ekstrak kedelai hitam diharapkan dapat menurunkan kadar glukosa darah. Glukosa darah merupakan produk akhir metabolisme glukosa. Salah satu faktor yang mempengaruhi kadar glukosa darah adalah hormon insulin dan glukagon. Kadar glukosa yang rendah, yaitu hipoglikemia dicegah dengan pelepasan glukosa, sedangkan kadar glukosa darah yang tinggi yaitu hiperglikemia dicegah oleh perubahan glukosa menjadi glikogen dan perubahan glukosa menjadi triasilgliserol di jaringan adiposa. $^{3}$
Beberapa penelitian tentang pengaruh antioksidan terhadap kadar glukosa darah memerlukan waktu selama 4 minggu agar hasil intervensi dapat terlihat pada kadar glukosa darah. ${ }^{16,23}$ Dalam penelitian ini pemberian ekstrak kedelai hitam dilakukan selama 2 minggu dan terjadi penurunan rerata kadar glukosa darah walaupun tidak secara signifikan. Hasil penelitian ini berbeda dengan penelitian Gina, yaitu pemberian ekstrak kedelai hitam selama 2 minggu dapat menurunkan kadar glukosa darah pada tikus SD. ${ }^{17}$

\section{Kadar Insulin}

Penelitian ini menunjukkan bahwa kadar insulin pada dosis 500 dan $750 \mathrm{mg} / \mathrm{kgBB}$ mengalami penurunan. Kelompok yang mengalami penurunan kadar insulin paling tinggi terlihat pada dosis $750 \mathrm{mg} / \mathrm{kgBB}$, sedangkan pada dosis $1000 \mathrm{mg} / \mathrm{kgBB}$ justru mengalami peningkatan. Hasil analisis statistik menunjukkan adanya perbedaan kadar insulin pada kelompok dosis $500 \mathrm{mg} / \mathrm{kg}$ dan dosis $750 \mathrm{mg} / \mathrm{kgBB}$. Hasil penelitian ini selaras dengan penelitian yang dilakukan Jang, dimana antosianin dapat menurunkan kadar insulin mencit yang diberi diet tinggi lemak. ${ }^{24}$

Ekstrak kedelai hitam mengandung antosianin yang berperan dalam menekan produksi TNF $\alpha$ dan mengurangi aktivasi potein kinase sehingga menghambat terjadinya inflamasi dan resitensi insulin. Berkurangnya produksi kinase akan meningkatkan 
fosforilasi tirosin IRS-1/IRS-2, aktivasi PI-3-kinase, dan downstream sinyal insulin. Mekanisme tersebut akan meningkatkan sintesis glikogen otot dan translokasi GLUT-4 di membran plasma. Sedangkan di hati, mekanisme tersebut akan meningkatkan sintesis glikogen hati, meningkatkan aktivasi glikogen sintase serta menurunkan glukoneogenesis hati. ${ }^{11,12}$

Berdasarkan hasil penelitian sebelumnya, dosis $1000 \mathrm{mg} / \mathrm{kgBB}$ justru mengalami peningkatan. Hasil analisis statistik menunjukkan adanya perbedaan dapat menurunkan kadar glukosa darah dan meningkatkan aktivitas SOD. ${ }^{17}$ Namun pada penelitian ini, dosis $1000 \mathrm{mg} / \mathrm{kgBB}$ justru meningkatkan kadar insulin. Tingginya dosis antioksidan dapat meningkatkan resiko pembentukan pro-oksidan. ${ }^{25}$ Peran antioksidan dalam menstabilkan radikal bebas adalah dengan melengkapi kekurangan elektron pada radikal bebas serta menghambat reaksi berantai dari pembentukan radikal bebas yang dapat menimbulkan stress oksidatif. ${ }^{13}$ Namun, pada kondisi tertentu seperti dosis antioksidan yang terlalu tinggi atau adanya ion tembaga $\left(\mathrm{Cu}^{2+}\right)$ dapat merubah antioksidan menjadi pro-oksidan. ${ }^{25}$

Flavonoid dapat mengubah $\mathrm{Cu}^{2+}$ menjadi $\mathrm{Cu}^{+}$, hal tersebut akan memicu terbentuknya radikal bebas. ${ }^{25}$ Jika kandungan flavonoid terlalu tinggi, maka jumlah ROS justru meningkat dan menurunkan sensitivitas insulin, sehingga sekresi hormon insulin akan ditingkatkan agar homeostasis glukosa dalam tubuh tetap terjaga.

\section{HOMA-IR}

Penelitian ini menunjukkan bahwa HOMA-IR pada semua kelompok perlakuan mengalami penurunan. Hasil analisis statistik menunjukkan adanya perbedaan HOMA-IR sebelum dan setelah perlakuan pada kelompok dosis $500 \mathrm{mg} / \mathrm{kg}$ dan $750 \mathrm{mg} / \mathrm{kgBB}$. Peningkatan maupun penurunan HOMA-IR ditentukan tinggi dan rendahnya kadar insulin dan kadar glukosa darah. Ekstrak kedelai hitam dengan dosis $500 \mathrm{mg} / \mathrm{kgBB}$ dan $750 \mathrm{mg} / \mathrm{kgBB}$ dapat menurunkan HOMA-IR. Hal ini menunjukkan bahwa ekstrak kedelai hitam berperan dalam memperbaiki kelainan metabolisme hormon insulin yaitu resistensi insulin.

\section{Selisih Kadar Glukosa Darah, Kadar Insulin, dan HOMA-IR}

Selisih kadar glukosa darah, kadar insulin, dan HOMA-IR diperoleh dari rerata sebelum perlakuan dikurangi rerata setelah perlakuan. Kelompok P1 memiliki selisih yang lebih besar jika dibandingkan dengan kelompok kontrol. Selisih rerata kadar glukosa, kadar insulin dan HOMA-IR terlihat semakin besar pada kelompok P2. Namun pada kelompok P3, selisih yang terjadi justru lebih kecil jika dibandingkan dengan kelompok P2. Hal ini dapat dikatakan bahwa dosis yang paling efektif dalam menurunkan kadar glukosa darah, kadar insulin dan HOMA-IR terdapat pada kelompok dosis $750 \mathrm{mg} / \mathrm{kgBB}$.

Berdasarkan hasil analisis, terdapat perbedaan ekstrak kedelai hitam terhadap selisih kadar insulin antar kelompok dosis. Hasil penelitian ini sejalan dengan penelitian yang dilakukan oleh Jang yang menunjukkan adanya perbedaan kadar insulin pada mencit yang diberi high fat diet. ${ }^{24}$

\section{Keterbatasan Penelitian}

Pembuatan simplisia ekstrak kedelai hitam membutuhkan waktu yang lebih lama karena kedelai harus dihaluskan secara manual yang dapat meningkatkan resiko kerusakan pada aktivitas antioksidan. Tidak dilakukan penimbangan sisa pakan sehingga jumlah pakan yang dikonsumsi hewan coba tiap harinya tidak dapat diketahui.

\section{SIMPULAN}

Hasil penelitian ini menunjukkan bahwa ekstrak kedelai hitam pada dosis 500 dan 750 $\mathrm{mg} / \mathrm{kgBB}$ dapat menurunkan kadar insulin dan HOMA-IR. Namun, tidak ada perbedaan kadar glukosa darah sebelum dan setelah perlakuan. Penurunan kadar glukosa darah, kadar insulin, dan HOMA-IR terbesar terdapat pada dosis $750 \mathrm{mg} / \mathrm{kgBB}$. Selanjutnya, perlu dilakukan penelitian lebih lanjut mengenai pengaruh ekstrak kedelai hitam terhadap kadar glukosa darah dengan durasi pemberian ekstrak minimal selama 4-8 minggu.

\section{DAFTAR PUSTAKA}

1. Lois K, Young J, Kumar S. Obesity: Epiphenomenon or cause of metabolic syndrome? Int. J. Clin. Pract. 2008; 62:932-8.

2. Despres JP, Lemieux I, Bergeron J, Pibarot P, Mathieu P, Larose E, et al. Abdominal obesity and the metabolic syndrome: Contribution to global cardiometabolic risk. Arterioscler. Thromb. Vasc. Biol. 2008; 28:1039-49.

3. Mayes PA. Glukonegenesis dan pengontrolan kadar glukosa darah. Dalam: Robert K. Murray, Daryl K Granner, Peter A. Mayes, Victor W. Rodwell. Biokimia Harper. Ed.27. Jakarta: EGC. 2009; hlm. 200-4.

4. Bano G. Glucose Homeostasis, obesity and diabetes. Best Practice and Research Clinical Obstetrics and Gynaecology. 2013; 27:715-26.

5. World Health Organization. Data and analysis of overweight and obesity. 2014. [cited Desember 2014]. Available from: http://www.who.int 
6. Roglic G, Unwin N. Mortality Attributable to diabetes: Estimates for the year. Diabetes Research and Clinical Practice. 2010; 87:15-19.

7. Eckel RH, Kahn SE, Ferrannini E, Goldfine AB,Nathan DM, Schwartz MW, et al. Obesity and type 2 diabetes: What can be unified and what needs to be individualized? Diabetes Care. 2011; 34:1424-30.

8. Kim JA, Wei Y, Sowers JR. Role of mitochondrial dysfunction in insulin resistance. Circ Res. 2008; 102:401-14.

9. Patarrão RS, Lautt WW, Macedo PP. Assessment of methods and indexes of insulin sensitivity. Rev Port Endocrinol Diabetes Metab. 2014; 9(1):65-73

10. Bolisetty S, Jaimes EA. Mitochondria and reactive oxygen species: Physiology and pathophysiology. Int. J. Mol. Sci. 2013; 14:630644.

11. Rains JL, Jain SK. Oxidative stress, insulin signaling and diabetes. Free Radic Biol Med. 2011; 50(5):567-75.

12. Halfon BS, Zick Y. Phosphorylation of IRS proteins, insulin action, and insulin resistance. Am J Physiol Endocrinol Metab. 2009; 296(4):581-91.

13. Kumar V, Rani A, Dixit AK, Pratap D, Bhatnagar D. A comparative assessment of total phenolic content, ferric reducing-anti-oxidative power, free radical-scavenging activity, vitamin c and isoflavones content in soybean with varying seed coat colour. Food Research International. 2010; 43: 323-8.

14. Nurrahman. Evaluasi komposisi zat gizi dan senyawa antioksidan kedelai hitam dan kedelai kuning. Jurnal Aplikasi Teknologi Pangan. 2015; 4(3):89-93.

15. Hong SH, Heo JI. Kim JH, Kwon SO, Yeo KM, Bakowska-Barczak AM, et al. Antidiabetic and beta cell-protection activities of purple corn anthocyanins. Biomol Ther (Seoul). 2013; 21(4):284-9.

16. Takikawa M, Inoue S, Horio F, Tsuda T. Dietary anthocyanin-rich bilberry extract ameliorates hyperglycemia and insulin sensitivity via activation of AMP-activated protein kinase in diabetic mice. J Nutr. 2010; 140(3):527-33.
17. Gina LP, Mahdi C, Aulanni'am. Therapy of black soybean (glycine max (l) merr) water extract on blood glucose and SOD activity of diabetes mellitus rats induced by MLD-STZ. The J. Pure App. Chem. Res. 2014; 3(3):131-7.

18. Yang ZH, Miyahara H, Takeo J, Katayama M. Diet high in fat and sucrose induces rapid onset of obesity-related metabolic syndrome partly through rapid response of genes involved in lipogenesis, insulin signalling and inflammation in mice. Diabetology \& Metabolic Syndrome. 2012; 4:32.

19. Campos KE, Volpato GT, Calderon IMP, Rudge MVC, Damasceno DC. Effect of obesity on rat reproduction and on the development of their adult offspring. Braz J Med Biol Res. 2008;41(2): 122-5.

20. Dahlan MS. Statistik untuk kedokteran dan kesehatan, Ed Ke-4. Jakarta: Salemba Medika. 2009. hlm. 114.

21. Kanamoto Y, Yamashita Y, Nanba F, Yoshida T, Tsuda T, Fukuda I, et al. A black soybean seed coat extract prevents obesity and glucose intolerance by up-regulating uncoupling proteins and down-regulating inflammatory cytokines in high-fat diet-fed mice. J. Agric. Food Chem. 2011; 59:8985-93.

22. Ghozali DS, Handharyani E, Rimbawan. pengaruh tempe terhadap kadar gula darah dan kesembuhan luka pada tikus diabetik. Cermin Dunia Kedokteran. 2010; 37(3):167-73.

23. El-Kordi EA, Alshahrani AM. Effect of genistein, a natural soy isoflavone, on pancreatic cells of streptozotocin-induced diabetic rats: histological and immunohistochemical study. Journal of Microscopy and Ultrastructure. 2015; 3:108-119.

24. Jang HH, Park MY, Kim HW, Lee YM, Hwang $\mathrm{KA}$, Park JH, et al. Black rice (oryza sativa 1.) extract attenuates hepatic steatosis in C57BL/6 J mice fed a high-fat diet via fatty acid oxidation. Nutrition \& Metabolism. 2012; 9:27.

25. Procházková D, Boušová I, Wilhelmová N. Antioxidant and prooxidant properties of flavonoids. Fitoterapia. 2011; 82(4):513-23 